\title{
透析患者における炭酸ランタンによる蛋白漏出性腸症
}

\author{
仲山 實 知念 隆之 $2^{2}$ 山里 将浩 ${ }^{3}$ \\ 与那原中央病院泌尿器科 ${ }^{1}$ 同消化器内科 ${ }^{2}$ 同内科 $^{3}$
}

キーワード：炭酸ランタン，蛋白漏出性腸症，好酸球性腸炎

〈要旨〉

60 代の男性．維持血液透析患者で，アレルギ一疾患の既往はなく，炭酸ランタン（La）の慎重投与とされる肝機 能障害, 消化管疾患はなかった. 炭酸 La を内服後, 高度の低アルブミン（Alb）血症が出現したが, 炭酸 La の中止 後, 急速に改善した. ${ }^{99 m} \mathrm{~T}$ c-HSA 蛋白漏出シンチグラフィーで回腸からの蛋白漏出が確認され, 蛋白漏出性腸症 （PLE）と診断された. 造影 CT スキャンで蛋白漏出部位と一致する回腸に，壁肥厚と内腔の狭小化が認められた.

また上部, 下部消化管の内視鏡検査と生検, 検便などから, 寄生虫疾患は除外された. 低 Alb 血症から回復した時 の造影 CT スキャンでは, 回腸の肥厚所見は消失していた. また, 回復後の炭酸 La の再投与によって, 末梢血好酸 球増多が確認された. 臨床経過から PLE の発症に炭酸 La の関与が考えられたが, 炭酸 La の投与で好酸球増多が 起こること, CT 画像で好酸球性腸炎に特徵的な小腸壁の肥厚が認められたこと, 寄生虫など他の疾患が除外され たことなどから，PLE の原因として好酸球性腸炎が疑われた．塩化ランタンのラットへの投与実験で胃粘膜下に高 率に好酸球の浸潤と末梢血の好酸球増多が観察され，また回腸の絨毛上皮にある Tight junction (TJ) の電子顕微鏡 観察の染色剂としてランタンは一般的に使用され，TJ から透過することが in vitro の実験で認められている. さら に炭酸 La の動物実験でも腸管への蓄積が認められ, 薬剤の臨床使用の有害事象に好酸球増多があるなどの知見も 炭酸 La による好酸球性腸炎の発症の可能性を示唆している. 自験例も, 薬剤の中止で軽快した臨床経過から炭酸 La による好酸球性腸炎と考えられた. 炭酸 La による蛋白漏出性腸症を伴った好酸球性腸炎の報告はまだないが, 使用にあたって念頭におく必要があると考え報告した.

\section{Protein-losing enteropathy induced by lanthanum carbonate in a dialysis patient}

Minoru Nakayama', Takayuki Chinen ${ }^{2}$ and Masahiro Yamazato ${ }^{3}$

Department of Urology ${ }^{1}$, Department of Gastroenterology ${ }^{2}$, and Department of Medicine ${ }^{3}$, Yonabaru Central Hospital

Key words : lanthanum carbonate, protein-losing enteropathy, eosinophilic-enteritis

〈Abstract〉

A male dialysis patient, who was in his sixties, showed no liver dysfunction or gastrointestinal disease, with which lanthanum carbonate must be used carefully. The patient developed marked hypoalbuminemia with a decrease in weight after taking lanthanum carbonate. A ${ }^{99 \mathrm{~m}} \mathrm{Tc}-\mathrm{HSA}$ protein-losing test revealed the leakage of HSA from the ileum and abdominal computed tomography showed ileal wall thickening. No evidence of parasitic disease was noted on stool examination. After lanthanum carbonate was discontinued, hypoalbuminemia abruptly improved. So, we believe that lanthanum carbonate was responsible for this protein-losing enteropathy. Although no histological studies of the affected ileum were conducted, it is suggested that the cause of protein-losing enteropathy in this case was eosinophilic-enteritis induced by lanthanum carbonate. The thickened ileum wall observed by computed tomography is a characteristic feature of eosinophilic-enteritis, and marked eosinophilia was demonstrated after using lanthanum carbonate in this case, which is one of the diagnostic criteria for eosinophilic-enteritis. There are biological studies providing suggestive evidence for the contribution of

仲山 實 与那原中央病院泌尿器科 $\bar{\top}$ 901-1303 沖縄県島尻郡与那原町字与那原 2905

Minoru Nakayama Tel : 098-945-8101 Fax : 098-945-8106

〔受付日：2011 年 7 月 1 日, 受理日：2011 年 8 月 24 日〕 
lanthanum carbonate to developing eosinophilic-enteritis. A toxicology study (animal experiments on rats) showed that long-term lanthanum carbonate exposure leads to the infiltration of eosinophils into the submucosa of the stomach with eosinophilia. Usually, lanthanum is used as a tracer in electron microscopic studies of the tight junction, and it was reported that ionic lanthanum penetrated through the tight junction of the rabbit ileum. Lanthanum may be absorbed through the epithelium of the ileum and induce an allergic reaction, leading to the development of eosinophilic enteritis. There has been no previous report of eosinophilic-enteritis induced by lanthanum carbonate. It should be kept in mind that lanthanum carbonate may be one of the causes of eosinophilic-enteritis.

\section{はじめに}

炭酸ランタン $(\mathrm{La})$ は, 慢性透析患者の経ロリン吸 着剂としての有効性で評価が高いが，その投与例で, 蛋白漏出性腸症 (protein-losing enteropathy : PLE) を発症した 1 例を経験したので，考察を加えて報告す る.

\section{I . 症 例}

症例は 60 代の男性. 慢性糸球体腎炎による慢性腎 不全で血液透析に導入され，血液透析歴 10 年である が, 重篤な透析合併症はみられず, 職業について社会 復帰をされており腎不全の自己管理も良好な透析症例 である．既往歴では， 6 年前に胃毛細血管拡張症から の消化管出血, 同時期に大腸ポリープに対しポリペク トミーを受けた．アレルギー疾患の既往はなく，炭酸 $\mathrm{La}$ の慎重投与が必要とされる肝機能障害, 消化管疾 患はなかった. $20 \mathrm{xx}$ 年の 4 月から, 高リン血症の治 療のため炭酸 La $750 \mathrm{mg}$ を投与したところ, 投与開始 から 1 か月後には血清アルブミン（以下 Alb）と血清 総蛋白 (以下 $\mathrm{TP}$ ) の明らかな低下を認め, 3 か月半後 には Alb $2.2 \mathrm{~g} / \mathrm{dL}, T P 3.9 \mathrm{~g} / \mathrm{dL}$ と著明に低下した (図 1).それに伴って，体重すなわちドライウェイト は, 投与開始後, 2 か月半頃から徐々に減少を始め, 炭 酸 La 中止後も低下が続き, 6 か月後には投与開始前 の体重 $59.5 \mathrm{~kg}$ から $55.2 \mathrm{~kg}$ と $4.3 \mathrm{~kg}$ の減少が起 こった，理学所見では，特記すべきことは認めず，悪 心, 嘔吐, 下痢, 腹痛等の消化器症状の訴えはほとん どなかった。

血液検査では Alb, TP, TIBC の低下がみられたが, 慢性腎不全を反映する他の検査值は, 投与前と大きな 変化はなかった．蛋白分画の結果では， $\alpha_{1}$ と $\alpha_{2}$ 分画が 上昇する急性炎症型を示したが, CRP の充進はなかっ た. ツベルクリン反応も陰性で, 便の潜血, 虫卵, 粪 線虫検査もいずれも㓌性であった（表 1). 4 か月目 に, ${ }^{99 \mathrm{~m}} \mathrm{Tc}-\mathrm{HSA}$ によ蛋白漏出シンチグラフィーを
行った. 6 時間までは蛋白の漏出は認めなかったが, 24 時間後の撮影で上行結腸から横行結腸に放射性同 位元素の集積を認めた. さらに，回腸と思われる小腸 にも淡い集積が認められた（図 2)。消化管の内視鏡検 査では, 胃では, びらん性胃炎があったが, 胃液蛋白 濃度は $71 \mathrm{mg} / \mathrm{dL}$ と正常範囲（正常值：250 mg/dL 以 下) ${ }^{1)}$ であった。 下部消化管では上行結腸に小ポリー プを認める以外, 回腸末端部から直腸まで異常を認め なかった. 胃, 十二指腸, 盲腸, 直腸から生検が行わ れ, 胃炎, 十二指腸炎, 非特異的大腸炎の病理診断で あった.アミロイド沈着はいずれの生検部位でも認め ず，また盲腸と直腸の生検標本で collagen band の形 成はみられず，アミロイドーシスと collagenous colitis は否定された. なお, 胃, 十二指腸, 盲腸, 直腸の 生検部位では, 粘膜下組織に好酸球の増加はみられな かった，造影 CT 検査では，臍の高さで，右側の小腸 おそらく回腸の, 壁の肥厚と内腔の狭小化がみられた (図 3a).この所見は, その後に低 Alb 血症が軽快し た時に行った造影 CT では, 消失していた（図 3b).

低 Alb 血症の発症時期と炭酸 La の投与開始とがほ ぼ一致することから，その関与が疑われたので，投与 開始から 5 か月後に，投与を中止した。 その結果，中 止後 2 週間目の Alb 值は 2.6 から 3.3 へ, TP は 4.5 から 5.6 へと急速な改善をみた（図 1).6 週間後には Alb と TP はそれぞれ 3.8, $6.3 \mathrm{~g} / \mathrm{dL}$ と回復し, その 後 Alb, TP の低下はみられなかった. ドライウェイ トも Alb, TP の回復に続いて 2 週間後から増加し炭 酸 La 中止 4 か月後には投与前の体重となった. 投与 中止の 8 か月後, 炭酸 La 1,500 mg が 7 日間投与され るという事態があったが，8日目に投与を中止した。 その時の白血球分画検査で, 投与前 $5.9 \%$ と正常で あった好酸球分画は, $24.2 \%, 1,500 / \mu \mathrm{L}$ と, 明らかな 好酸球増加症（>700/ $\mu \mathrm{L} ）$ が認められた。 ちなみに, $\operatorname{IgE}$ は正常であった. なお, 早期の投薬中止によって 消化器症状や Alb, TP の低下は出現せず, その後も みられていない. 


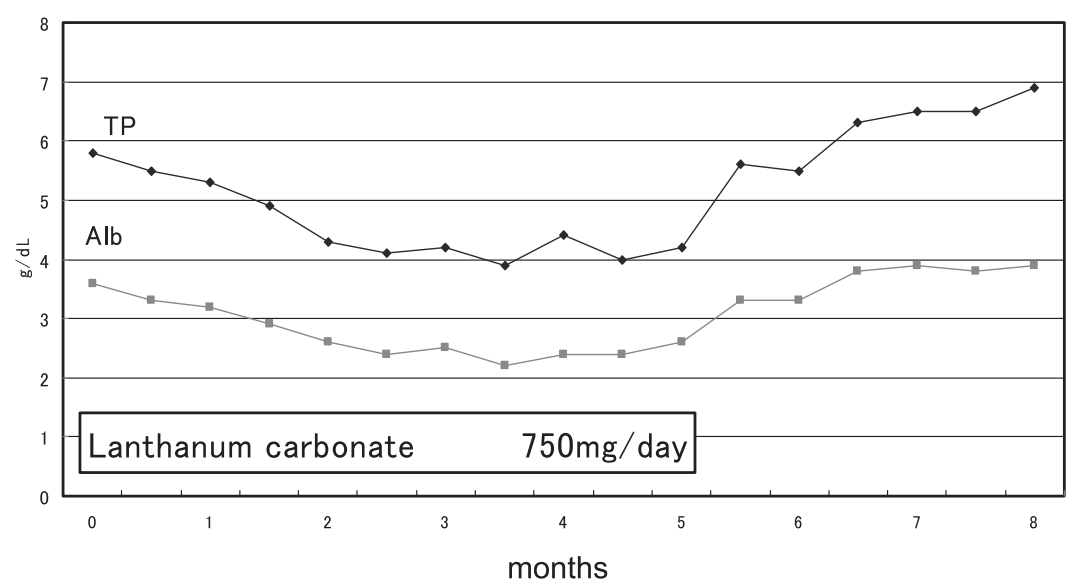

図 1 Relationship between lanthanum carbonate and Alb or TP.

表 1 Laboratory investigation results

\begin{tabular}{|c|c|c|c|}
\hline WBC & $7,400 / \mu \mathrm{L}$ & BUN & $93 \mathrm{mg} / \mathrm{dL}$ \\
\hline $\mathrm{Hb}$ & $11 \mathrm{~g} / \mathrm{dL}$ & $\mathrm{Cr}$ & $13 \mathrm{mg} / \mathrm{dL}$ \\
\hline Hct & $34.5 \%$ & UA & $7 \mathrm{mg} / \mathrm{dL}$ \\
\hline Plet & $27 \times 10^{4} / \mu \mathrm{L}$ & $\mathrm{Na}$ & $136 \mathrm{mEq} / \mathrm{L}$ \\
\hline $\mathrm{TP}$ & $3.9 \mathrm{~g} / \mathrm{dL}$ & $\mathrm{K}$ & $5.4 \mathrm{mEq} / \mathrm{L}$ \\
\hline $\mathrm{Alb}$ & $2.2 \mathrm{~g} / \mathrm{dL}$ & $\mathrm{Cl}$ & $101 \mathrm{mEq} / \mathrm{L}$ \\
\hline $\mathrm{FE}$ & $43 \mu \mathrm{g} / \mathrm{dL}$ & $\mathrm{Ca}$ & $9.8 \mathrm{mg} / \mathrm{dL}$ \\
\hline TIBC & $182 \mu \mathrm{g} / \mathrm{dL}$ & $\mathrm{P}$ & $6.4 \mathrm{mg} / \mathrm{dL}$ \\
\hline CRP & $0.06 \mathrm{mg} / \mathrm{dL}$ & PTH & $207 \mathrm{pg} / \mathrm{mL}$ \\
\hline GOT & $26 \mathrm{IU} / \mathrm{L}$ & Stool & occult blood $\quad(-)$ \\
\hline GPT & $25 \mathrm{IU} / \mathrm{L}$ & & ova $(-)$ \\
\hline ALP & $205 \mathrm{U} / \mathrm{L}$ & & strongyloides $(-)$ \\
\hline LDH & 209 IU/L & PPD & $(-)$ \\
\hline
\end{tabular}

\section{II. 考察}

炭酸 La は，経口による腸管内でのリン吸着効果に 優れ，維持透析患者の高リン血症治療薬として評価が 高い ${ }^{2)}$. 今回われわれは, 炭酸 $\mathrm{La}$ の投与例で蛋白漏出 性腸症による低 Alb，低夕ンパク血症を発症した症例 を経験した，炭酸 La の使用調査では副作用で重篤な ものはなく, 悪心, 嘔吐が主なもので゙), 蛋白漏出性腸 症の報告はない。本例の低 Alb, 低タンパク血症は, 炭酸 La 投与後に発症し, 中止によって消失したこと から，原因として炭酸 La の関与が示唆された.

蛋白漏出性腸症とは，下痢や嘔吐で血漿蛋白が失わ れる病態ではなく，腸粘膜上皮から血漿タンパク，と くにアルブミンが異常漏出することによって生じる低 $\mathrm{Alb}$ ，低夕ンパク血症を主徴とする症候群である。原 因疾患として，リンパ系の異常（腸リンパ管拡張症, 悪性リンパ腫など)，血管透過性が関与するもの (SLE : systemic lupus erythematosus, アミロイドー シスなど), 腸粘膜上皮の炎症によるもの（メネトリ
エール病，クローン病，潰瘍性大腸炎，腸結核，悪性 腫瘍, 好酸球性腸炎など) がある ${ }^{4)}$ 。 また, 薬凨（メソ トレキセート, サイクロスポリン $\mathrm{A}$, カルバマゼピン, 非ステロイド系抗炎症薬など5)）によるものなど多彩 な原因がある。したがって，蛋白漏出性腸症の診療に おいては，その原因疾患を診断することは，治療を行 う上で第一に行うべきことである，その観点から本例 の蛋白漏出性腸症の原因疾患について, 検討を行った. 本例では, リンパ系の疾患, 血管透過性が関与する 疾患は否定され，また上記の原因薬剂も服用していな かった，本例の蛋白漏出性腸症の病変部位は，蛋白漏 出シンチグラフィーから回腸の一部と思われ, 造影 $\mathrm{CT}$ で漏出部位に一致する回腸の壁肥厚と内腔の狭小 化が認められた。そして腸粘膜上皮の炎症性疾患のう ち, 好酸球性腸炎以外の疾患は上部, 下部消化管の内 視鏡検査などから除外され，低 Alb，低タンパク血症 の回復後に炭酸ランタンの再投与によって好酸球増多 が出現した事実や CT 所見から, 原因疾患として好酸 球性腸炎が疑われた。

好酸球性腸炎は消化管へ好酸球の浸潤をきたす原因 が明らかではない比較的まれな疾患で, 症例の約半数 にアレルギー性疾患が合併し，特定の食品や薬剤の服 用後に発症することから，発症にアレルギーの関与が 想定されている ${ }^{6)}$ ，そして好酸球性腸炎を起こす薬剤 として, カルバマゼピン, リファンピシン, アザチオ プリン ${ }^{7)}$, 非ステロイド系抗炎症薬 ${ }^{8}$ などが知られてい る. 好酸球性腸炎の確定診断には生検が必要とされる が，本例では病変が小腸に存在したため内視鏡検査を 容易に行えないという制約があり，生検の診断が困難 であった。それで, Talley $ら^{7)}$ の好酸球性腸炎の診断 基準に基づいて検討した。 三つのクライテリアがあ り, 


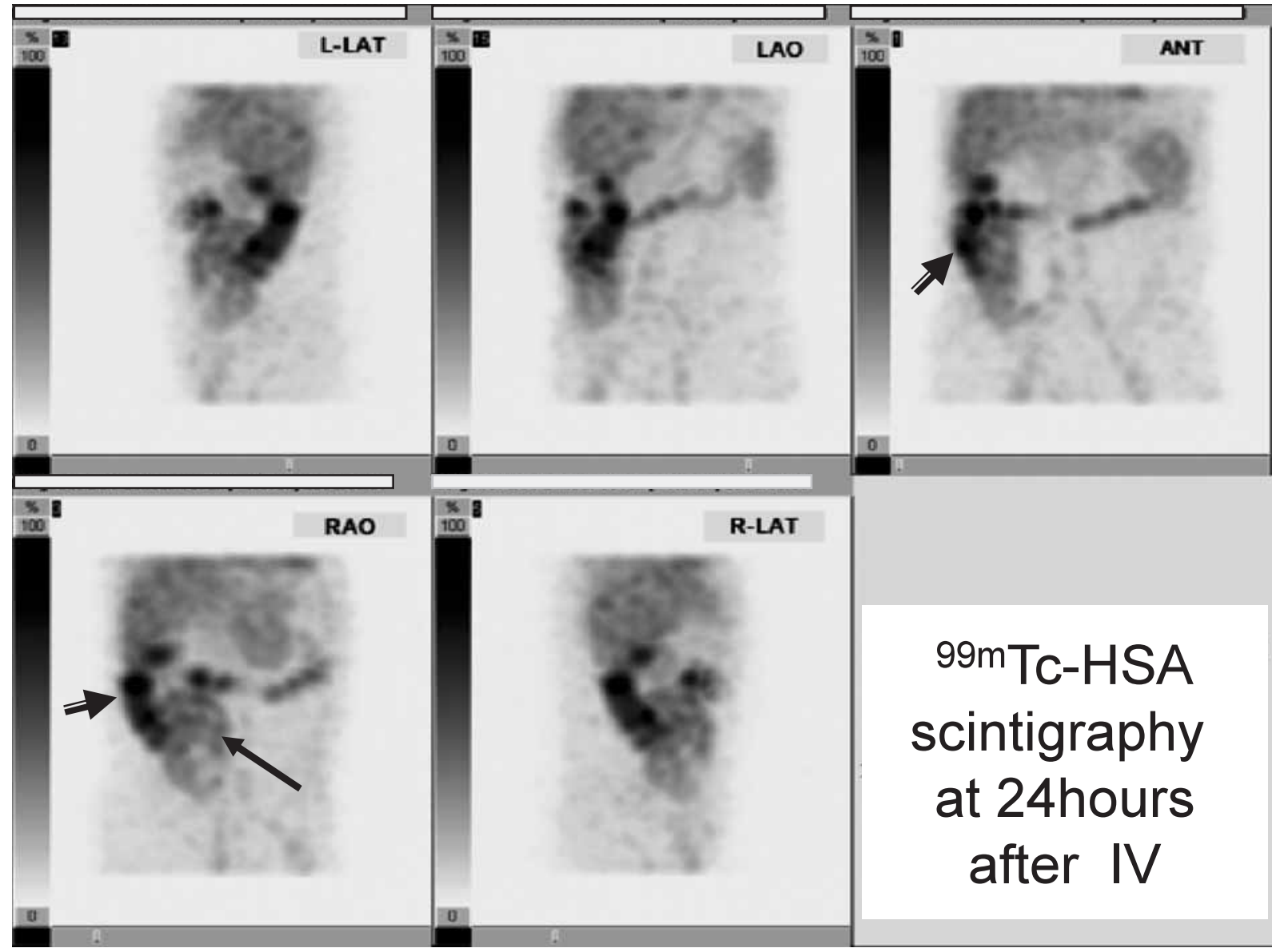

図 $2^{99 \mathrm{~m}} \mathrm{Tc}$-HSA protein-losing scintigraphy. The ileum $(\longleftarrow)$, the ascending colon $(\rightarrow)$

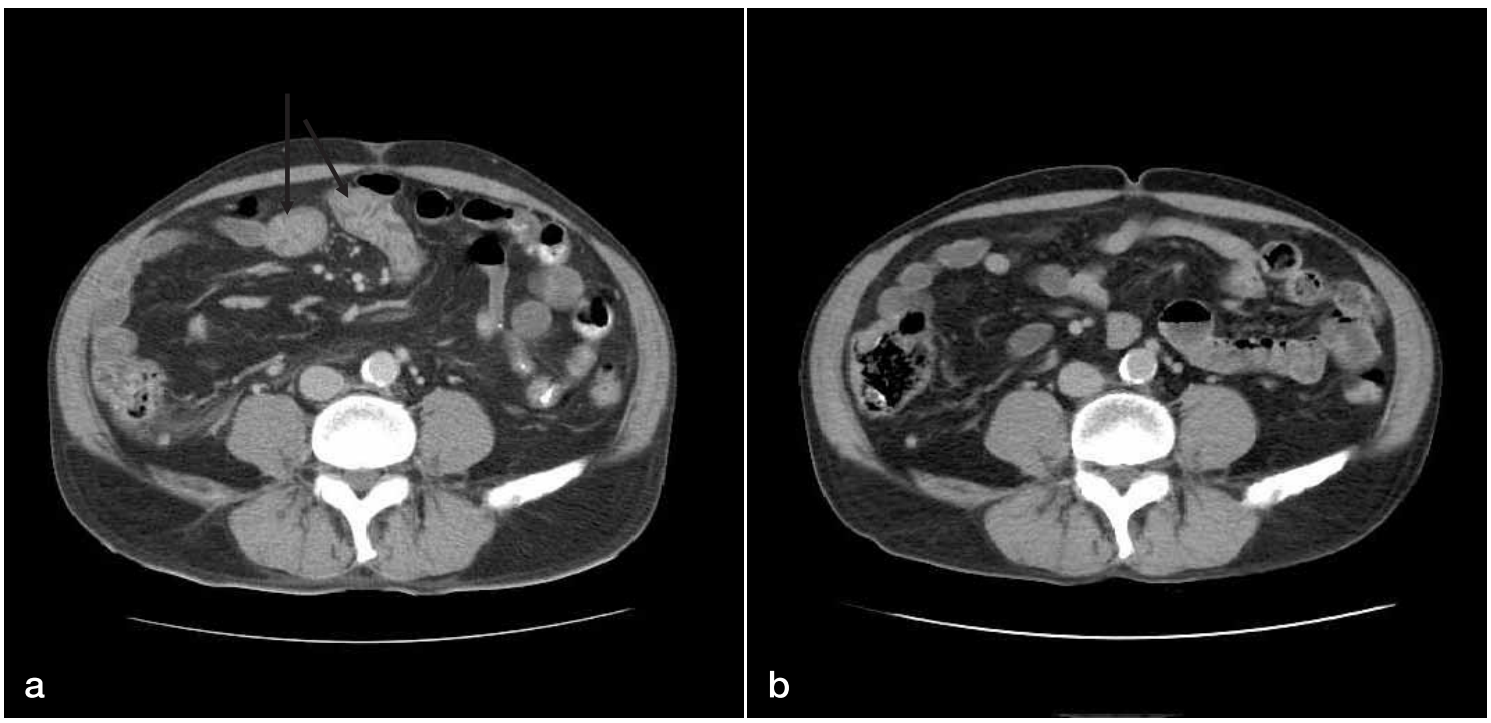

図 3 a : Abdominal enhanced CT. Wall thickening of the ileum $(\longleftarrow$ $\mathrm{b}$ : Enhanced CT at the recovery from PLE

1 ）消化管症状が存在すること.

2 ) 消化管の 1 箇所以上に生検で好酸球浸潤が証明 されるか, または末梢血好酸球増多と特徴的な X 線所見がみられる。
3 ）寄生虫など好酸球増多を示す他疾患が除外でき ること。

の 3 項目を満たすことと規定されている.

本例は, 蛋白漏出シンチで回腸壁からの蛋白のリー 
クが証明されており，蛋白漏出性腸症の症状があり，

1）は満たし，また2）については生検を施行していな いが, 造影 CT で腸壁の肥厚, 内腔の狭小化の特徴的 な X 線所見があった. 未梢血好酸球増多については, 発症時の白血球分画を施行しておらず好酸球増多の有 無は不明だったが，後日，腸炎が軽快して後，偶々， 炭酸 La が 7 日間投与された時に行った白血球分画 で, $24.2 \%, 1,500 / \mu \mathrm{L}$ (正常 : $<450 / \mu \mathrm{L}$ ) の好酸球増 多を認めた。この結果から, 炭酸 La はアレルゲンと して作用すると判断され, 発症時も好酸球増多が起 こっていたことが推察された。 したがって，2）のクラ イテリアの“または末梢血好酸球増多と特徵的な $\mathrm{X}$ 線所見がみられる”を満たすと判断した. クライテリ ア3）については，内視鏡検査や他の除外診断目的の 検査で寄生虫疾患が除外できているので，好酸球性腸 炎の診断クライテリアに矛盾しないと考えられた.

好酸球性腸炎の症状は, 好酸球の浸潤が起こる消化 管の部位, 消化管壁の層によって異なった症状が出現 するのが特徴である．好酸球の浸潤が粘膜に優位な症 例では, 非特異的な腹部不快感, 吸収不良, 蛋白漏出 性腸症がみられ, 一方, 筋層優位な例では閉塞の症状, すなわち腹部膨満感や嘔気がみられる。また漿膜下優 位なものでは閉塞症状と腹水がみられる ${ }^{9}$.

本例は, 消化管疾患を思わせる症状がほとんどな かった点は, 消化管疾患が存在したのか疑問が生ずる. 蛋白漏出性腸症から，おそらく粘膜優位の好酸球性腸 炎と考えられ, 本来, 症状も非特異的な腹部不快感を 示す程度と考えられるが, 蛋白漏出シンチグラフィー で確認されたように, 蛋白漏出が緩徐で著明でないこ とや, 造影 CT で認めた回腸の病変部位が限局的だっ たことが, 比較的軽い炎症反応をもたらし, 消化器症 状を軽微にしたと思われた。 また, 蛋白漏出性腸症そ のものも, 嘔吐, 下痢, 腹痛などの消化器症状をほと んど伴わないので ${ }^{10)}$, 本例において消化管疾患を疑う 症状がみられなかったのは, 消化管疾患を否定するも のではない.むしろ消化管症状がないことが特徽的な 所見と捉えるべきで，本例では，それが診断に時間を 費やしてしまった原因になったことに留意すべきであ る.

ところで, 本例では好酸球性腸炎の原因となる薬剤, カルバマゼピン, リファンピシン, アザチオプリン, 非ステロイド系抗炎症薬などは投与されておらず，好 酸球性腸炎の原因として炭酸 La が示唆される. その 理由として, 炭酸 Laの投与を契機として発症し,さ らに中止で軽快した臨床経過があげられる。これは, 好酸球性肺炎などでも観察される特徵的な臨床経過
で，原因薬劑を中止するだけで疾患が軽快するパター ンである.

さらに，好酸球性腸炎と炭酸 La の関連性を示唆す る好酸球性腸炎の病態に関する興味深い基礎的研究結 果がある。好酸球性腸炎の起こる機序についての最近 の知見では, 食物や薬品などの物質がアレルゲンに なって好酸球が消化管に浸潤し, eosinophil major basic protein, cytotoxic cationic protein などを遊離する ことで炎症を起こし, さらに, IL-3, IL-5, GM-CSF, etotaxin な゙のサイトカインやケモカインの分泌に よって他の好酸球の浸潤を促進し, 炎症が進行すると いう仮説がたてられている6). 一方, 動物を用いたラ ンタンの投与実験で, ランタンが好酸球性腸炎を発症 させるアレルゲンとして作用することを示唆する結果 が示されている.

小川 ${ }^{11)}$ はラットを用いたランタンの毒性の基礎的研 究で, 28 日間経口連続投与により胃の粘膜下組織に好 酸球の浸潤が認められ, 末梢血の好酸球増多も確認さ れたと報告している.さらに投与終了後 14 日間の無 投与期間をおいた回復群では, 好酸球の浸潤は消失し ており，回復傾向が認められた。この実験では，基本 的に不溶性である炭酸 La とは大きく異なる, 溶解性 が高い塩化ランタンを使用していることを考慮する必 要がある. また, 実験で塩化ランタンの体重 $1 \mathrm{~kg}$ あ たりの 1 日投与量は $1,000 \mathrm{mg}$ で, 体重 $50 \mathrm{~kg}$ の人へ の投与量に換算すると, 炭酸 La の臨床的に使用が承 認された最高容量の約 20 倍にあたる。 その条件の違 いから, 炭酸 La の経口投与がリスクがあるとは決し ていえないが, 炭酸 La の内服においても, ランタン が腸管の粘膜内に吸収された場合, 同様に好酸球の浸 潤が起こる可能性を示唆している。 また, ランタンの 中止後, 好酸球浸潤も消失した事実は, ランタンが抗 原となったアレルギー反応を表している。したがっ て, この研究報告はランタンの内服によって好酸球性 腸炎が発症する可能性を示している.

ここで, 内服した炭酸 La は果たして塩化ランタン のように消化管から吸収されるかが問題となる。これ まで, 炭酸 La は殆ど腸管から吸収されないと強調さ れてきたが, 動物実験では消化管と腸間膜リンパ節に 蓄積が確認され, 消化管からの吸収が明らかにされて いる ${ }^{12)}$. また, 臨床使用例においても腸管からの吸収

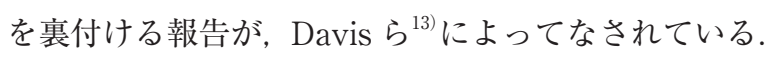
彼らは炭酸 La を 3 年間投与された慢性腎不全の症例 で，腸間膜リンパ節のマクロファージに，ランタンが 貪食されて沈着している例を報告し, 長期間の投与に よって炭酸 La が腸管から吸収され, リンパ節などへ 
沈着する影響など，その長期毒性の可能性を調查研究 する必要があると述べている。これらの報告から，炭 酸 $\mathrm{La}$ による好酸球性腸炎の発症の可能性は否定でき ないと思われる。

さらに，ランタンの消化管からの吸収に関して，く しくも小腸粘膜の上皮における tight junction (TJ)の 電子顕微鏡による実験で染色剂としてランタンが用い られ，回腸粘膜上皮の TJ からランタンの透過吸収が 起こることが報告されている ${ }^{14)}$.この結果から, 回腸 あるいは回盲部の粘膜上皮は, ランタンの吸収が起こ る可能性が高いと考えられる。一方で，TJ は腸管か らの蛋白漏出の経路になり, 炎症反応の過程で生じた $\mathrm{TNF} \alpha, \mathrm{IFN} \gamma$ などのサイトカインによって透過性が 克進し, 腸管からの蛋白漏出が起こることも明らかに されている ${ }^{15)}$.これらの知見は，本例における蛋白漏 出性腸症を伴った好酸球性腸炎の病態を説明しうると 思われる.すすねわち, 回腸の TJ から吸収されたラン タンによって遅延型のアレルギー反応から好酸球性腸 炎が発症し，その結果生じた好酸球浸潤などで誘導さ れたサイトカインによって，回腸の絨毛細胞間の TJ の透過性が光進して蛋白リークが生じたと思われる.

それから, 炭酸 $\mathrm{La}$ と好酸球性腸炎の関連を推測さ せる事実として，好酸球増多が炭酸 $\mathrm{La}$ の有害事象と して報告されていることがあげられる，炭酸 La の薬 剤情報によればその頻度は $1 \%$ 未満と記載されてい る ${ }^{16)}$. しかし, Hutchison $ら^{3)}$ の報告によれば，好酸球 増多の頻度が 6 か月投与の解析では言及されていない が， 2 年投与では $1.9 \%$ と長期投与で増加がみられる. また臨床使用前の動物実験でも炭酸 La の消化管への 蓄積は投与期間に比例して増加することが観察されて いる ${ }^{12}$. したがって長期投与で腸管への蓄積が起こ り，アレルギー反応が促進されて好酸球增多例が増加 することが推察され，その場合炭酸 Laによる好酸球 性腸炎の増加も予想され，今後その発症に注意を払う 必要がある。そして，この問題に関連して，炭酸 $\mathrm{La}$ の臨床報告で気になる報告がある。

好酸球性腸炎は，前述のように好酸球の浸潤部位が 粘膜優位の場合は, 症状も軽く, 原因薬剤や食物の中 止で劇的に軽快し比較的良性の経過をとるが，一方， 筋層あるいは漿膜下浸潤型では腸管穿孔, 虚血性腸炎, 腸管閉塞など重篤な病態となる。最近透析患者の炭酸 $\mathrm{La}$ 投与例で, 腸閉塞, 虚血性腸炎, 腸穿孔が回盲部, 回腸に発症した例の報告がみられる ${ }^{17 \sim 19)}$ 。これらの例 と好酸球性腸炎の筋層あるいは漿膜下浸潤型との関連 性が危惧されるので，好酸球性腸炎を念頭においた病 態解明が望まれる。
好酸球性腸炎の治療は，食物あるいは薬剂アレル ギーの原因が明らかな場合は，その食品あるいは薬郕 を㠌取制限することで改善が期待される。また，治療 薬として副腎皮質ステロイドの投与が行われる ${ }^{6}$. そ して消化管狭窄や穿孔などの重症化例には外科的治療 が必要となるが，いずれの場合も腸管に不可逆的な変 化が起こる前に早期に診断し治療を行うのが原則であ る、したがって本例の反省からいえることだが，炭酸 $\mathrm{La}$ 投与症例には積極的に末梢血白血球分画を行い, 好酸球増多の確認を行うべきことを強調したい.

稿を終えるにあたり，放射線画像診断にご指導をいた だきました，当院放射線診断部の大城 潔先生，ならび に伊良波裕子先生に深謝いたします。

本症例は, 第 56 回日本透析医学会学術集会·総会 $(2011$

年，横浜）で発表した。

\section{文献}

1）野村昌哉, 井上善文, 藤田繁雄, 阪尾 淳, 廣田昌紀, 宗田滋夫，大嶋正人：胃部分切除術を施行した巨大な 蛋白漏出性胃癌の 1 例. 日消外会誌 $38: 412-417$, 2005

2) Sigematsu $T$, The Lanthanum Carbonate Research Group : Three-year extension study of lanthanum carbonate therapy in Japanese hemodialysis patients. Clin Exp Nephrol $14:$ 589-597, 2010

3) Hutchison AJ, Maes B, Vanwalleghem J, Asmus G, Mohamed E, Schmieder R, Backs W, Jamar R, VossKühler A : Long-term efficacy and tolerability of lanthanum carbonate : results from a 3-year study. Nephron Clin Pract 102:61-71, 2006

4）渡辺知佳子, 穂刈量太, 三浦総一郎 : 蛋白漏出性腸症 の病態と診断. 胃と腸 $43: 731-734,2008$

5) Gracey M, Anderson CM : Intestinal lymphangiectasia and other causes of protein-losing gastroenteropaties. In "Paediatric Gastroenterol Hepatology" ed Gracey M, Burke V, 439-440, Blackwell Scientific Pub, Oxford, London, 1993

6）木下芳一：好酸球性胃腸炎. 別冊日本臨牀；新領域別 症候群シリーズ No. 11, 消化管症候群（第 2 版）(上), 465-468, 日本臨牀社, 大阪, 2009

7) Tally NJ, Shorter RG, Phillips SF, Zinsmeister AR : Eosinophilic gastroenteritis : a clinicopathological study of patients with disease of the mucosa, muscle layer, and subserosal tissues. Gut 31 : 54-58, 1990

8）八尾隆史, 松本主之, 飯田三雄, 蔵原晃一, 広田千治, 岩井啓一郎, 恒吉正澄: 非ステロイド系抗炎症剤 (NSAID) 起因性腸炎の病理組織学的特徵と鑑別診断. 胃と腸 35 : 1159-1167, 2000

9) Wolpin BM, Weller PF, Katz JT, Levy BD, Loscalzo J : 
Clinical problem-solving. The writing on the wall. N Engl J Med 361 : 1387-1392, 2009

10) Redelmeier DA : New thinking about postoperative hypoalbuminemia : a hypothesis of occult proteinlosing enteropathy. (オンライン) Open Medicine, Vol 3, No 4 (2009). http://www.openmedicine.ca/article/ viewArticle/343/280,（参照 2011/04/14）

11）小川幸男：ランタンの生体影響に関する研究一ラット における連続強制経口投与一. Jpn J Toxicol Environ Health 38 : 545-553, 1992

12) Public Assessment report Scientific discussion Fosrenol July 12, 2006. SE/H/481/01-04/E01

13) Davis RL, Abraham JL : Lanthanum deposition in a dialysis patient. Nephrol Dial Transplant 24 : 32473250, 2009

14) Machen TE, Erlij D, Wooding FB : Permiable junctional complexes-The movement of lanthanum across rabbit gallbladder and intestine. J Cell Biol 54 : 302312, 1972

15) Bode L, Salvestrini C, Park PW, Li JP, Esko JD,
Yamaguchi Y, Murch S, Freeze HH : Heparan sulfate and syndecan-1 are essential in maintaining murine and human intestinal epitherial barrier function. J Clin Invest 118 : 229-238, 2008

16）JAPIC 医療用医薬品添付文書：0005630 商品名ホスレ ノール 2011/05/25 版

17）岩見奈帆子, 中川理恵, 山下 歩, 高安澄江, 小林祐 子, 藤澤佳美, 小松魅侑爾, 村井豊秀, 高橋郁夫 : レ ントゲンから判明した炭酸ランタンの問題点. 透析会 誌 44(Suppl 1)：742, 2011

18）中山 均, 菊池 博, 斎藤徳子, 島田久基, 宮崎 滋, 酒井信治, 鈴木正司：炭酸ランタン内服中に回盲部か ら上行結腸にランタン貯留を生じた 3 例. 透析会誌 $44($ Suppl 1) : 520, 2011

19）森 慶太, 越川真男, 明石健吾, 西倉哲司, 嶋津啓二, 高折光司, 西口健介, 村上 徹, 依藤壮史, 江口恵梨 子, 田中敬雄, 仙崎英人, 桑原 隆: 炭酸ランタンの 腸管内遺残を認めた血液透析患者の 1 例. 透析会誌 $43: 853-857,2010$ 